\title{
Influence of Amazonian deforestation on the future evolution of regional surface fluxes, circulation, surface temperature and precipitation
}

\author{
Quentin Lejeune · Edouard L. Davin • \\ Benoit P. Guillod · Sonia I. Seneviratne
}

Received: 18 January 2014/ Accepted: 26 May 2014/Published online: 6 July 2014

(c) The Author(s) 2014. This article is published with open access at Springerlink.com

\begin{abstract}
The extent of the Amazon rainforest is projected to drastically decrease in future decades because of land-use changes. Previous climate modelling studies have found that the biogeophysical effects of future Amazonian deforestation will likely increase surface temperatures and reduce precipitation locally. However, the magnitude of these changes and the potential existence of tipping points in the underlying relationships is still highly uncertain. Using a regional climate model at a resolution of about $50 \mathrm{~km}$ over the South American continent, we perform four ERAinterim-driven simulations with prescribed land cover maps corresponding to present-day vegetation, two deforestation scenarios for the twenty-first century, and a totally-deforested Amazon case. In response to projected land cover changes for 2100 , we find an annual mean surface temperature increase of $0.5^{\circ} \mathrm{C}$ over the Amazonian region and an annual mean decrease in rainfall of $0.17 \mathrm{~mm} /$ day compared to present-day conditions. These estimates reach $0.8^{\circ} \mathrm{C}$ and $0.22 \mathrm{~mm} /$ day in the total-deforestation case. We also compare our results to those from 28 previous (regional and global) climate modelling experiments. We show that the historical development of climate models did not modify the median estimate of the Amazonian climate sensitivity to deforestation, but led to a reduction of its uncertainty. Our results suggest that the biogeophysical effects of deforestation alone are unlikely to lead to a tipping point in the evolution of the regional climate under present-day climate
\end{abstract}

Electronic supplementary material The online version of this article (doi:10.1007/s00382-014-2203-8) contains supplementary material, which is available to authorized users.

Q. Lejeune $(\varangle)$ · E. L. Davin · B. P. Guillod · S. I. Seneviratne Institute for Atmospheric and Climate Science, ETH Zürich, Zürich, Switzerland

e-mail: quentin.lejeune@env.ethz.ch conditions. However, the conducted synthesis of the literature reveals that this behaviour may be model-dependent, and the greenhouse gas-induced climate forcing and biogeochemical feedbacks should also be taken into account to fully assess the future climate of this region.

Keywords Land-use and land-cover changes . Amazonian deforestation - Tipping points - Twenty-first century

\section{Introduction}

Recent international environmental summits have recognized the importance of forests in acting as a carbon sink for the climate system, and therefore advocated international efforts to curb deforestation (UNFCCC, 15th Conference of the Parties 2009). However, replacement of forests by agricultural land or urban environments has other climatic consequences. Deforestation indeed perturbs not only the carbon fluxes, but also the energy and water fluxes between forests and the atmosphere, because it modifies the physical characteristics of the land surface, such as its albedo, evapotranspiration, and roughness (Bonan 2008). Pongratz et al. (2010) and de Noblet-Ducoudré et al. (2012) have shown that for historical land-use and land-cover changes (LULCC), these biogeophysical climatic impacts could have been regionally as strong or even stronger than the biogeochemical ones (i.e. those related to the associated carbon emissions to the atmosphere).

Thus, biogeophysical effects have to be taken into account in order to fully assess future climate changes, especially in regions where anthropogenic modifications of land cover are expected to be large in the future. Amazonia is one of them: Deforestation has intensely taken place 
there since the 1970s (Fearnside 2005), with a gross deforestation rate as high as $\sim 25,000 \mathrm{~km}^{2} \mathrm{y}^{-1}$ in the 1990s (Achard et al. 2002); the forest is now still shrinking, and the pressure for more agricultural land is likely to continue. Observations show that in Amazonia, pastures have a higher albedo than forests, but lower roughness lengths and evapotranspiration rates (Jipp et al. 1998; von Randow et al. 2004). Consequently, while the deforestation-induced increase in albedo tends to cool the surface by decreasing net solar radiation amount, the decreases in evapotranspiration and roughness length have a warming effect. Less evapotranspiration indeed means a lower latent heat flux, which is compensated by a higher sensible heat flux and tends to increase near-surface temperature. Additionally, a lower roughness length leads to a reduced turbulent transport of heat to the atmosphere, hence to heat accumulation close to the surface. In spite of these opposite effects, modelling studies overall agree that deforestation in Amazonia locally leads to temperature increases, even if the spread between models is large (d'Almeida et al. 2007). In the same way, a decrease in precipitation over the Amazonian basin was generally modelled in response to local deforestation. A first explanation for this result is that the local input of water to the atmosphere through evapotranspiration is lowered, which reduces precipitation recycling within the Amazonian basin (Eltahir and Bras 1993). Besides, some modelling studies found that atmospheric moisture input in the basin would be reduced due to deforestation, thereby amplifying the diminution of precipitation. However, this response of large-scale circulation and its impact on moisture convergence is debated in the literature (Marengo 2006).

The first modelling studies investigating the biogeophysical impacts of future Amazonian deforestation used Global Circulation models (GCMs) with relatively coarse resolutions (from 1.8 to $7.5^{\circ}$, e.g. Dickinson and Henderson-Sellers 1988; Lean and Warrilow 1989; Nobre et al. 1991). They performed similar idealised experiments in which they replaced the Amazonian forest by grassland, but the spread in the magnitude of the simulated climate impacts is high. Many studies were realised by the same modelling centers, which successively published follow-up studies in which they used the same model but implementing revised parameterisations and/or increased resolution, in order to improve the representation of both current and post-deforestation climates.

In the late 2000s, similar modelling studies using mesoscale-resolution regional climate models (RCMs) $\left(\sim 0.2-0.5^{\circ}\right)$ have been published (e.g. Moore et al. 2007; Ramos da Silva et al. 2008; Walker et al. 2009). Their higher resolution presents several advantages. Firstly, the spatial variability of climate conditions is better represented than in large grid cells. Secondly, it allows to resolve explicitly some of the biggest mesoscale phenomena that bring an important part of precipitation over this region (Greco et al. 1990), which is not well assessed by the parameterisation schemes of lower-resolution GCMs (Dai 2006). Lastly, increased resolution makes the implementation of more complex and more finely-resolved land cover maps as surface conditions possible. These represent realistic scenarios of future land covers based on the current land settlement and on various economic assumptions. However, because of the increase in computational demand, the RCM experiments conducted by Moore et al. (2007), Ramos da Silva et al. (2008) and Walker et al. (2009) were limited to 2 months or 1 year, and may thus be affected by spin-up effects. Those three studies provided a limited estimation of interannual variability, in running each experiment several times but forced by boundary conditions corresponding to observations from four or five different years. Besides, they used a domain restricted to the Amazonian region, and forced by lateral boundary conditions based on current observations. Hence, noticing that RCM studies generally simulated a smaller response of precipitation to deforestation, Medvigy et al. (2011) questioned the ability of RCMs to fully assess the climate response to future LULCC over Amazonia, because they might miss feedbacks involving non-local, atmospheric or oceanic processes. Even if no systematic comparison of GCMs and RCMs has been carried out to confirm this conjecture, the latter are by design more suitable to finely investigate the local to regional changes in surface fluxes and their impacts on climate, than to study the whole climate response to deforestation.

In the 2000s, several studies also started to investigate whether the deforestation-induced evolution in climate conditions over Amazonia would exhibit nonlinear effects. In spite of ongoing deforestation, observations indeed do not provide clear evidence for a decrease in precipitation yet (d'Almeida et al. 2007). However, it has sometimes been suggested that beyond a certain threshold, the lower evapotranspiration rates of grassland would lead to a major decrease in precipitation recycling, which could considerably weaken the hydrological cycle in this region (d'Almeida et al. 2007; Avissar et al. 2002). Following this hypothesis, a tipping point could then be reached, after which a dramatic and strongly nonlinear decrease of precipitation would lead to permanent drier conditions and potentially to perturbations of the local ecosystems.

Here we use an RCM to assess the biogeophysical effects of possible scenarios of LULCC on the South American climate. To investigate possible tipping points and the linearity of these changes, we prescribe different levels of Amazonian deforestation corresponding to the 
current vegetation distribution, two scenarios for the twenty-first century, and a total deforestation case. We aim to reduce the above-mentioned limitations of previous RCM studies by running our simulations over a multidecadal period, and for a simulation domain encompassing the whole South America. Besides, since the good representation of land surface processes and their feedbacks with the atmosphere is an important requirement for an accurate representation of climate (Bonan 2008; Koster et al. 2010; Seneviratne et al. 2010; Davin et al. 2011), we use a state-of-the-art Land Surface Model (LSM). To assess uncertainties about the modelled regional climate response to Amazonian deforestation, we then compare our results to previously published similar RCM and GCM experiments. We also investigate whether more recent studies using latest model versions tend to reach a consensus on the magnitude of the mean deforestation-driven climate changes for the Amazonian region.

Our methodology is described more extensively in Sect. 2. In Sect. 3, we evaluate the ability of the employed model to represent the current climate over South America, and present the results of our simulations. In Sect. 4, we finally conduct a comparative analysis of over 25 similar deforestation experiments from the literature and describe its results.

\section{Methods and data}

\subsection{Model description}

We use the climate model COSMO-CLM ${ }^{2}$ (Davin et al. 2011; Davin and Seneviratne 2012), which consists of the atmospheric component of the COSMO-CLM RCM (version COSMO4.8-CLM11) coupled to the version 3.5 of the Community Land Model (CLM3.5) for the simulation of land surface processes.

The COSMO-CLM RCM is widely used for climate studies and for weather forecasting purposes; an extensive description of the model is available at http://www.clmcommunity.eu. In this study, we use 32 vertical layers to represent the 23 first kilometers of the atmosphere, with a higher density of levels next to the surface. Vertical turbulent mixing is parameterised according to a level 2.5 closure using Turbulent Kinetic Energy as a prognostic variable (Mellor and Yamada 1974, 1982). We use the mass flux scheme of Tiedtke (1989) for parameterisation of subgrid moist convection and a four-category 1-moment cloud-ice scheme including cloud water and rainwater, snow and ice for large-scale precipitation.

CLM3.5 is a state-of-the-art third-generation LSM. It uses 10 vertical levels to model areas covered by both soils (up to a depth of $3.5 \mathrm{~m}$ ) and lakes. This model can represent five subgrid land cover types: vegetation, lake, glacier, wetland and urban area, each one occupying a determined fraction of each grid cell. The portion covered by vegetation is further divided into fractions of each Plant Functional Type (PFT). Each PFT represents a particular plant type, defined in the model by various optical, morphological and physiological parameters and is a separate column for energy and water calculations. Over Amazonia, the most abundant PFTs are broadleaf evergreen tropical tree, broadleaf deciduous tropical tree, grasses (C3 and C4), and crops.

CLM3.5 has been evaluated at the global scale by Oleson et al. (2008), and in the context of COSMO-CLM ${ }^{2}$ by Davin et al. (2011), Davin and Seneviratne (2012) and Lorenz et al. (2012). Over South America, CLM3.5 showed a good representation of hydrological processes in comparison to other land surface models, for example in simulating the water table depth in Amazonia (Fan and Miguez-Macho 2010). However, it still exhibits some biases, for example an overestimated latent heat flux compared to observations (Lawrence et al. 2011). It has also been reported that ground evaporation in CLM3 and CLM3.5 tends to overly compensate changes in plant transpiration when leaf area index diminishes (Lawrence and Chase 2007; Lorenz et al. 2013), which may lead to a lower sensitivity of evapotranspiration to deforestation than in reality.

\subsection{Description of the experiments}

All simulations were performed over the domain used for the Coordinated Regional climate Downscaling EXperiment (CORDEX) intercomparison (Fig. 1a), which covers the whole of South America with a horizontal resolution of $0.44^{\circ}$ (Solman et al. 2013). Each simulation was run over the time period 1979-2010 with a time step of $150 \mathrm{~s}$, the first 8 years being used as spinup time, while the next 24 years were analysed in this study. For both atmospheric lateral boundary conditions and sea surface temperatures, we used the ERA-Interim reanalysis (Dee et al. 2011). The greenhouse gas concentrations were prescribed to those observed during the period covered by the reanalysis data, while a seasonal cycle of aerosols was also prescribed.

We performed four simulations with COSMO-CLM ${ }^{2}$, differing only in terms of their vegetation characteristics, as summarized in Table 1 . The vegetation map of the control simulation (CTL) is the standard vegetation map of CLM3.5 (Lawrence and Chase 2007). It is primarily based on a separation of land cover types between bare soil, forested, and herbaceous areas following MODIS satellite data from 2001 (Hansen et al. 2003), while the crop fraction is adapted from Ramankutty and Foley (1999). The DEF_A2 experiment was conducted using a land cover 
Table 1 Characteristics of the vegetation maps in the different experiments: state of the land cover they represent, source of the data of vegetation cover or method to obtain them, and fraction of grid cells occupied by grasslands, croplands and trees

\begin{tabular}{|c|c|c|c|c|}
\hline Simulation & CTL & DEF_50\% & DEF_A2 & DEF_TOT \\
\hline State of land cover map & $\begin{array}{l}\text { Current } \\
\text { vegetation }\end{array}$ & $\begin{array}{l}\text { Intermediate state } \\
\text { between CTL and } \\
\text { DEF_A2 }\end{array}$ & $\begin{array}{l}2100 \text { vegetation map according to the } \\
\text { A2 scenario (Nakicenovic et al. } \\
2000 \text { ) }\end{array}$ & $\begin{array}{l}\text { total deforestation in tropical } \\
\text { South America }\end{array}$ \\
\hline $\begin{array}{l}\text { Data source for the land } \\
\text { cover map }\end{array}$ & $\begin{array}{l}\text { Lawrence and } \\
\text { Chase (2007) }\end{array}$ & $\begin{array}{l}\text { Linear interpolation } \\
\text { between the two other } \\
\text { maps }\end{array}$ & IMAGE model (IMAGE team 2001) & $\begin{array}{l}\text { Suppression of trees and linear } \\
\text { extrapolation for other PFTs }\end{array}$ \\
\hline $\begin{array}{l}\text { Fraction of grid cells } \\
\text { occupied by } \\
\text { grasslands }\end{array}$ & $30 \%$ & $21 \%$ & $11 \%$ & $11 \%$ \\
\hline $\begin{array}{l}\text { Fraction of grid cells } \\
\text { occupied by croplands }\end{array}$ & $3 \%$ & $35 \%$ & $66 \%$ & $89 \%$ \\
\hline $\begin{array}{l}\text { Fraction of grid cells } \\
\text { occupied by trees }\end{array}$ & $65 \%$ & $44 \%$ & $22 \%$ & 0 \\
\hline
\end{tabular}

Given percentages are averages over the Amazonian region, which is defined as follows: from $14^{\circ} \mathrm{S}$ to $2^{\circ} \mathrm{N}$, and from $72^{\circ}$ to $45^{\circ} \mathrm{W}$, here and thereafter (see also red box in Fig. 1a)

Fig. 1 a Map showing the domain used for the simulation (black line), the area used for averaging over the Amazonian region (red line) and the transect used for the cross-sections shown on Fig. 5 (blue line). Colours show the cumulated percentage of trees in each grid cell in the control simulation. b, $\mathbf{c}$ and $\mathbf{d}$ Zooms on the

Amazonian basin showing the cumulated percentages of trees in the DEF_50\% (b), DEF_A2 (c) and DEF_TOT

(d) experiments

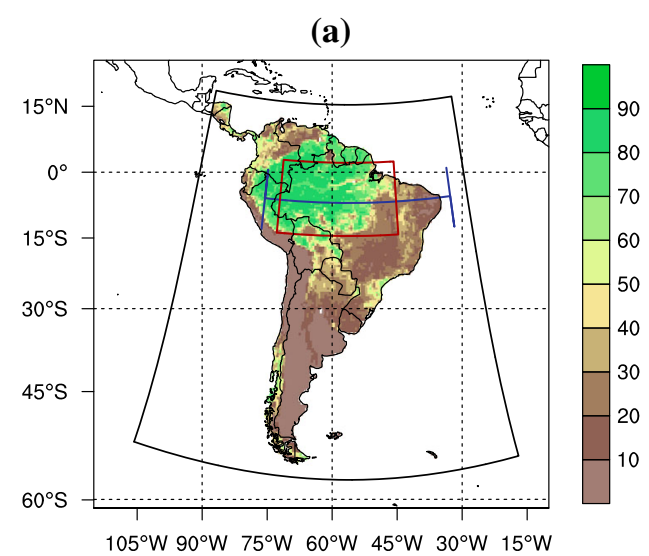

(c) DEF_A2

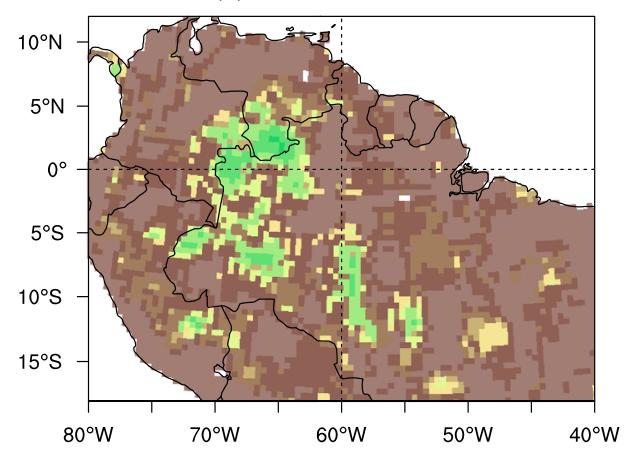

(b) DEF_50\%



(d) DEF_TOT

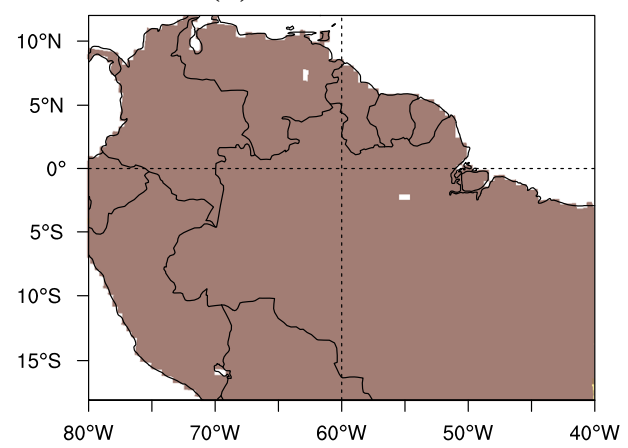

map for the year 2100, developed by the IMAGE 2.2 landuse change model (IMAGE team 2001), following the A2 storyline (Nakicenovic et al. 2000). Due to the assumptions of strong population growth and of regionalization of the future world economy, it predicts high deforestation rates in the tropics. Another experiment is forced by a land cover map which reflects an intermediate level of these modifications. This latter experiment is hereafter referred to as DEF_50\%, as it was obtained by linear interpolation, halfway between the percentages of each PFT in the control and the DEF_A2 case, for each grid cell. A last experiment (DEF_TOT) was conducted with a land cover map in which percentages of all types of trees were set up to 0 , for each grid cell within $-20^{\circ} \mathrm{S}$ to $20^{\circ} \mathrm{N}$, and 80 to 
(a)

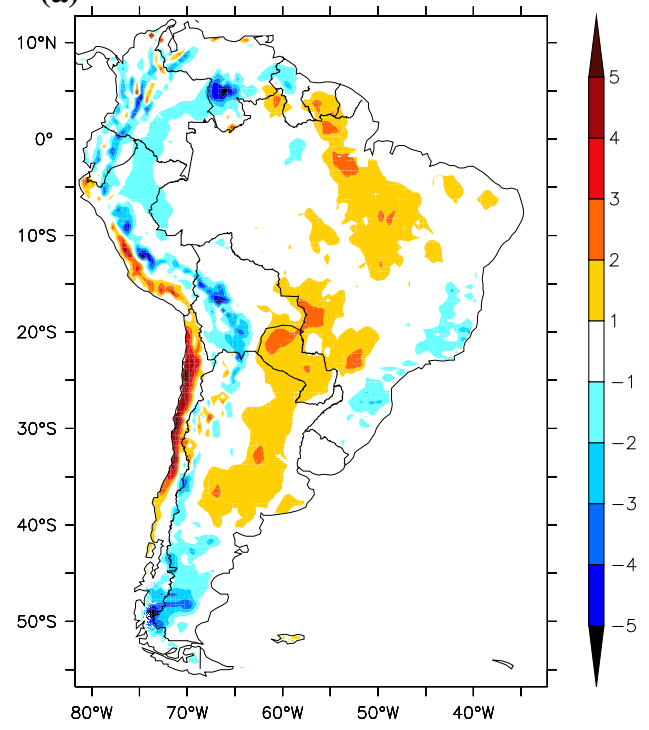

(b)

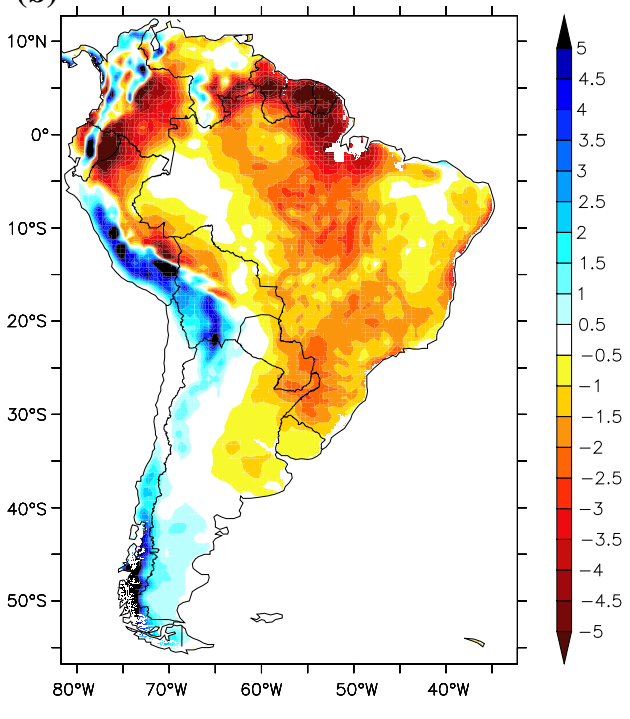

Fig. 2 Differences in annual mean 2-m temperature $\left(\mathbf{a}\right.$, in $\left.{ }^{\circ} \mathrm{C}\right)$ and precipitation $(\mathbf{b}$, in $\mathrm{mm} /$ day $)$ between the control simulation and observations (CRU), for the period 1987-1995

$40^{\circ} \mathrm{W}$ (i.e. tropical South America, roughly). The percentages of other PFTs were defined by extrapolation of the linear trend between the control and DEF_A2 scenarios in each grid cell, so that for all PFTs (trees included), the rate of change between the DEF_A2 and DEF_TOT maps was the same as between the control and DEF_A2 scenarios. These three maps hence describe a "linear evolution" of deforestation, which enables us to study possible nonlinear effects of deforestation on climate.

For each simulation, the average amounts of trees, grasslands and crops in the Amazonian region $\left(14^{\circ} \mathrm{S}-2^{\circ} \mathrm{N}, 72-45^{\circ} \mathrm{W}\right.$, see red box in Fig. 1a) are given in Table 1. Figure 1 shows the cumulated percentages of the 8 PFTs belonging to the tree class, for each of the four experiments. We only show a zoom over Amazonia for the DEF_50\%,DEF_A2 and DEF_TOT experiments, as this is where the most important LULCC occur.

\section{Results}

\subsection{Model evaluation}

We evaluate the ability of COSMO-CLM ${ }^{2}$ to represent current climate by comparing the simulated $2-\mathrm{m}$ temperature and precipitation fields in the control simulation with observations from the CRU dataset (Mitchell and Jones 2005) over the 1987-1995 period (Fig. 2). Biases in 2-m temperature are limited over Amazonia; however there is a substantial cold bias over the Andes $\left(1-4^{\circ} \mathrm{C}\right)$, while surface temperature is partially overestimated by $1-3{ }^{\circ} \mathrm{C}$ on a roughly North-South strip stretching from the Guianas to Northern Patagonia. This bias reaches a maximum in September, October and November (SON, not shown). It is likely linked to an important underestimation of precipitation amounts east of the Andes chain, and is highest over the Guianas, the mouth of the Amazon river and the foothills of the Andes where it can locally reach $5 \mathrm{~mm} /$ day (Fig. 2b). This means that almost all precipitation is suppressed in these regions, which likely influences the sensitivity of the simulated climate to deforestation. This quite important bias is not an isolated problem, as most of the climate models evaluated in the framework of the IPCC 4th and 5th assessment reports exhibited the same tendency to underestimate rainfall over this region (Joetzer et al. 2013; Yin et al. 2013; Randall et al. 2007). Interestingly, COSMO-CLM $^{2}$ presents biases of similar magnitude and over the same regions as the mean of an ensemble of recent versions of 7 RCMs run over the same domain, with the same resolution and also forced with ERA-Interim reanalysis data (cf. Solman et al. 2013). Hence, the deforestation experiments presented in this study were conducted with a model presenting the average performance and biases of state-of-the-art RCMs. Even if the characteristic rainfall features of South America, like the maxima over Amazonia, the Intertropical Convergence Zone and the South Atlantic Convergence Zone are correctly captured by the model (not shown), the shortcomings of the model should be kept in mind while analysing the results of our simulations. 
(a)
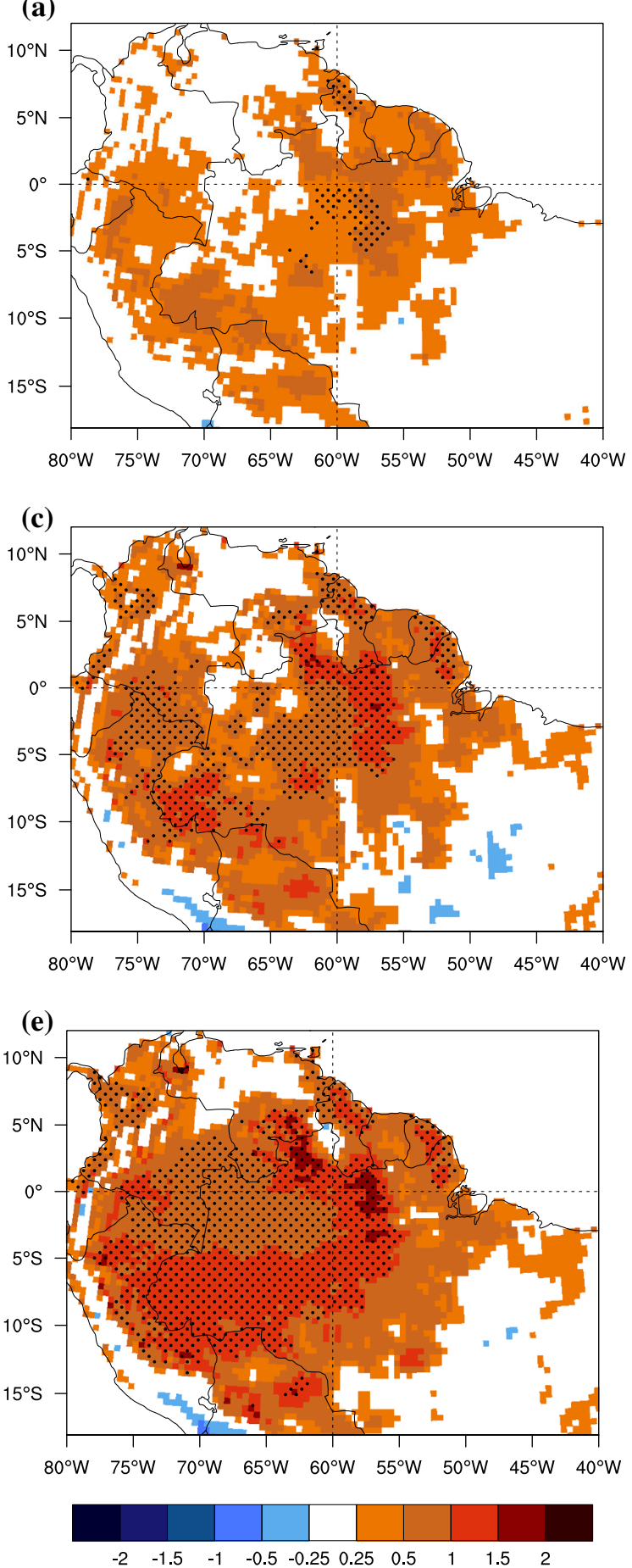

Fig. 3 Deforestation-induced annual mean anomalies in 2-m temperature $\left(\mathbf{a}, \mathbf{c}, \mathbf{e}\right.$, in $\left.{ }^{\circ} \mathrm{C}\right)$ and precipitation $(\mathbf{b}, \mathbf{d}, \mathbf{f}$, in $\mathrm{mm} /$ day) in the DEF_50\% (a, b), DEF_A2 (c, d) and DEF_TOT $(\mathbf{e}, \mathbf{f})$ simulations
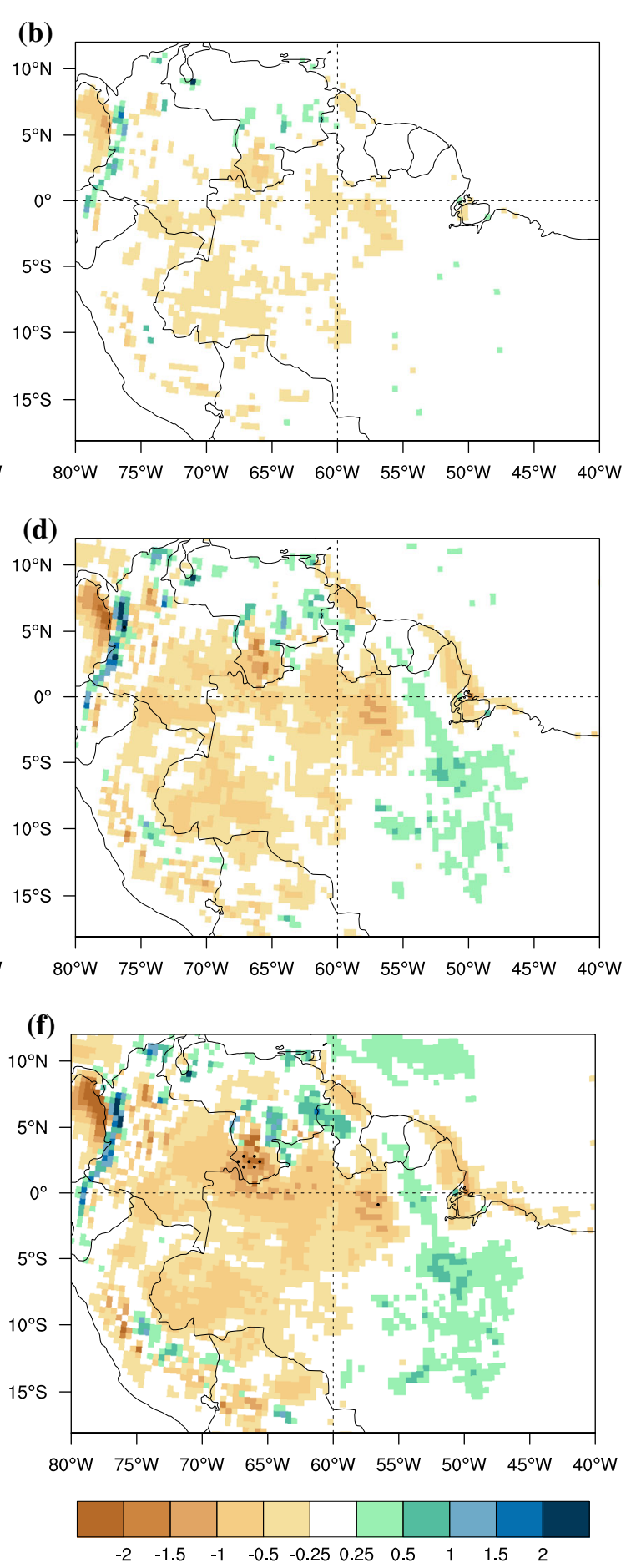

compared to CTL, for the period 1987-2010. Changes that are different from 0 at the $5 \%$ significance level after evaluation with a two-tailed $t$ test are marked by stippling 
3.2 Regional effects of deforestation on surface fluxes, circulation, surface temperature and precipitation

\subsubsection{Evolution of surface temperature with deforestation and its link to surface energy fluxes}

The changes in annual mean 2-m temperature in the deforestation experiments compared to CTL (Fig. 3a, c and e) indicate a warming over deforested areas, which matches well the deforestation pattern (see Fig. 1). The average increase in 2-m temperature over the Amazonian region increases with the extent of deforestation, reaching $0.29^{\circ} \mathrm{C}$ in DEF_50\%, $0.53{ }^{\circ} \mathrm{C}$ in DEF_A2 and $0.78^{\circ} \mathrm{C}$ in DEF_TOT (Table 2). In DEF_A2, the warming becomes statistically significant at the $5 \%$ level over extensive areas. This evolution scales well with the amount of deforestation, i.e. changes in surface temperature are proportional to changes in the area covered by trees (Table 2). This, as well as the good match between the pattern of the warming and that of deforestation, indicates that the surface temperature response is determined by changes in surface properties. Among these properties, the albedo, the emissivity, the root depth, the leaf area index and the roughness length of the vegetation, are all modified through the prescribed extent of deforestation.

The albedo increases linearly with the amount of trees that is replaced by crops and grasslands (Table 2). Cloud feedbacks modify incoming shortwave radiation by no more than $1 \mathrm{~W} / \mathrm{m}^{2}(0.5 \%)$, while their impact on incoming longwave radiation is close to scale with the prescribed amount of deforestation in our simulations (Table 2). This is also the case for outgoing longwave radiation, which is modified by changes in ground temperature and in emissivity. Consequently, changes in net radiation (both shortwave and longwave) also closely follow such a linear evolution on average over the Amazonian basin. We find that this decrease in net incoming radiation almost exclusively translates into a linear diminution of the latent heat flux on both regional (Table 2) and local scales (not shown), while the sensible heat flux is modified by less than $0.5 \mathrm{~W} / \mathrm{m}^{2}(1.6 \%)$. This decrease of the latent heat flux results firstly from the reduction in vegetation cover, which diminishes both interception and transpiration. Secondly, due to reduced precipitation amounts, the soil moisture content decreases, which means that less water is available for evapotranspiration. Thirdly, grasses have shallower roots than trees, and can therefore not access water stored deeply. Overall, the effect of the decrease in latent heat flux dominates over that of the albedo increase, hence leading to the simulated warming, consistently with most previous studies (e.g. Davin and Noblet-Ducoudré 2010 and other studies reported in Table 3). The good scaling of variations in surface energy fluxes with the prescribed amount of deforestation results in the fact that, in our simulations, 2-m air temperature is also proportional to the extent of deforestation. This is not a self-evident result, as physical processes relating surface temperature and energy fluxes are not expected to be all linear.

The analysis of the mean seasonal cycle of 2-m temperature over the Amazon region confirms the close link between surface energy fluxes, in particular the latent heat flux, and air surface temperature. Figure 4a indeed reveals that the surface warming occurs all year round, but also that the maximum anomalies occur at the end of the dry season, i.e. the time of the year when soil moisture levels are at their lowest point. Von Randow et al. (2004) observed that, during the dry season, evapotranspiration is sustained in forested areas but not over pastures, because trees have deeper roots than grasses, which enable them to access water stored more deeply. This behaviour is captured by the model, the deforestation-induced decrease in evapotranspiration being largest at the end of the dry season (not shown). These interactions between land surface processes and the hydrological cycle explain the amplification of the warming at that time of the year.

In addition to the local effect of the surface energy budget, surface temperature is also affected by the circulation of warm or cold air masses. However, the fact that changes in surface temperature scale with the extent of

Table 2 Average values over the Amazonian region for several climatic variables (left column), and their corresponding changes in deforestation experiments

\begin{tabular}{lllll}
\hline & CTL & DEF_50\% & DEF_A2 & DEF_TOT \\
\hline Trees & $100 \%$ & $66 \%$ & $33 \%$ & 0 \\
T2m & 26.42 & +0.29 & +0.53 & +0.78 \\
albedo & 0.145 & +0.011 & +0.022 & +0.034 \\
SW down & 189.6 & -0.6 & -0.3 & +1.0 \\
SW up & 27.5 & +2.0 & +4.1 & +6.7 \\
LW down & 410.1 & +1.1 & +2.1 & +2.8 \\
LW up & 456.1 & +2.8 & +5.4 & +7.9 \\
Rn & 116.1 & -4.2 & -7.7 & -10.8 \\
LH & 83.9 & -3.9 & -7.6 & -11.5 \\
SH & 30.6 & +0.5 & -0.4 & +0.14 \\
P & 4.15 & -0.11 & -0.17 & -0.22 \\
E & 2.9 & -0.13 & -0.26 & -0.4 \\
P-E & 1.25 & +0.02 & +0.09 & +0.18 \\
\hline
\end{tabular}

From top to bottom: percentage of trees compared to CTL, 2-m temperature, albedo, downward and upward shortwave radiation at the surface, downward and upward longwave radiation at the surface, net radiation at the surface, latent heat flux, sensible heat flux, precipitation, evapotranspiration and precipitation minus evapotranspiration. Temperature is given in ${ }^{\circ} \mathrm{C}$, energy fluxes in $\mathrm{W} / \mathrm{m}^{2}$, and water fluxes in $\mathrm{mm} /$ day 
Fig. 4 Mean Seasonal Cycles of 2-m temperature (a, in $\left.{ }^{\circ} \mathrm{C}\right)$ day) averaged over the Amazonian region, for the CTL, DEF_50\%,DEF_A2 and DEF_TOT simulations and of precipitation (b, in $\mathrm{mm} /$
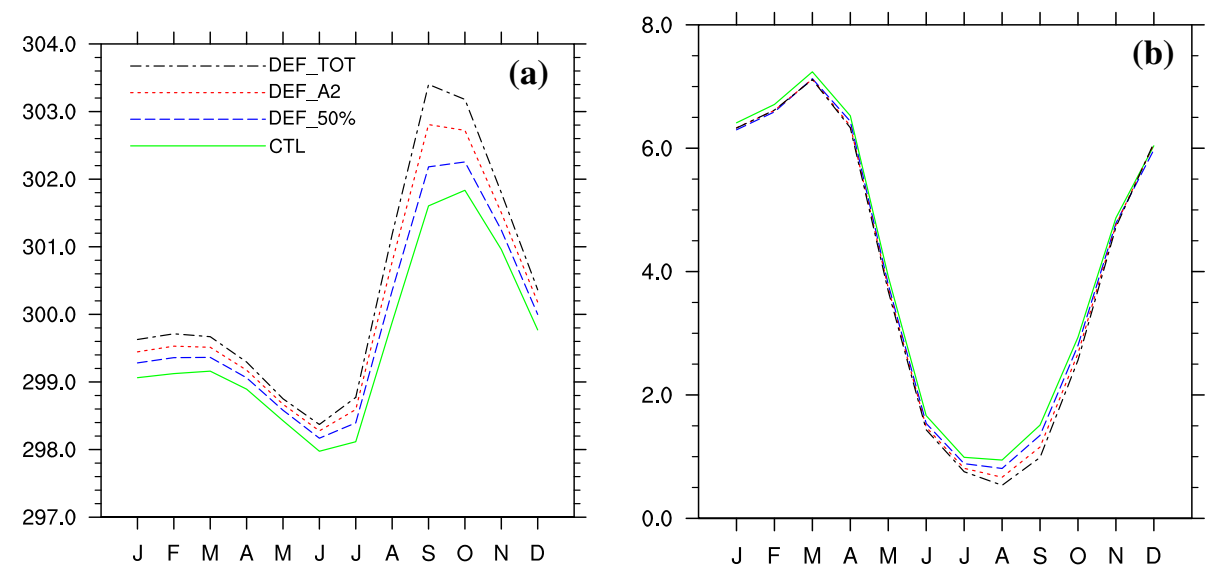

Fig. 5 Longitudinal crosssections showing annual mean changes in several variables in the DEF_TOT simulation compared to CTL, along the transect drawn on Fig. 1. Values are averaged latitudinally over a $12^{\circ}$-wide band. Upper panel changes in vertical (filled contours) and zonal wind velocities (contour lines) with altitude. Contour lines are drawn every $0.1 \mathrm{~m} / \mathrm{s}$, and dashed lines indicate an increase in mean wind speed in the westward direction. 2nd, 3rd and 4th panels: mean changes in precipitation $(\mathrm{P})$,

evapotranspiration (E) and in precipitation minus

evapotranspiration (P-E), in $\mathrm{mm} /$ day. 5th panel: changes in the sum of latent and sensible heat fluxes, in $\mathrm{W} / \mathrm{m}^{2}$. Lower panel: absolute amount of trees in CTL, in \% of the grid cells

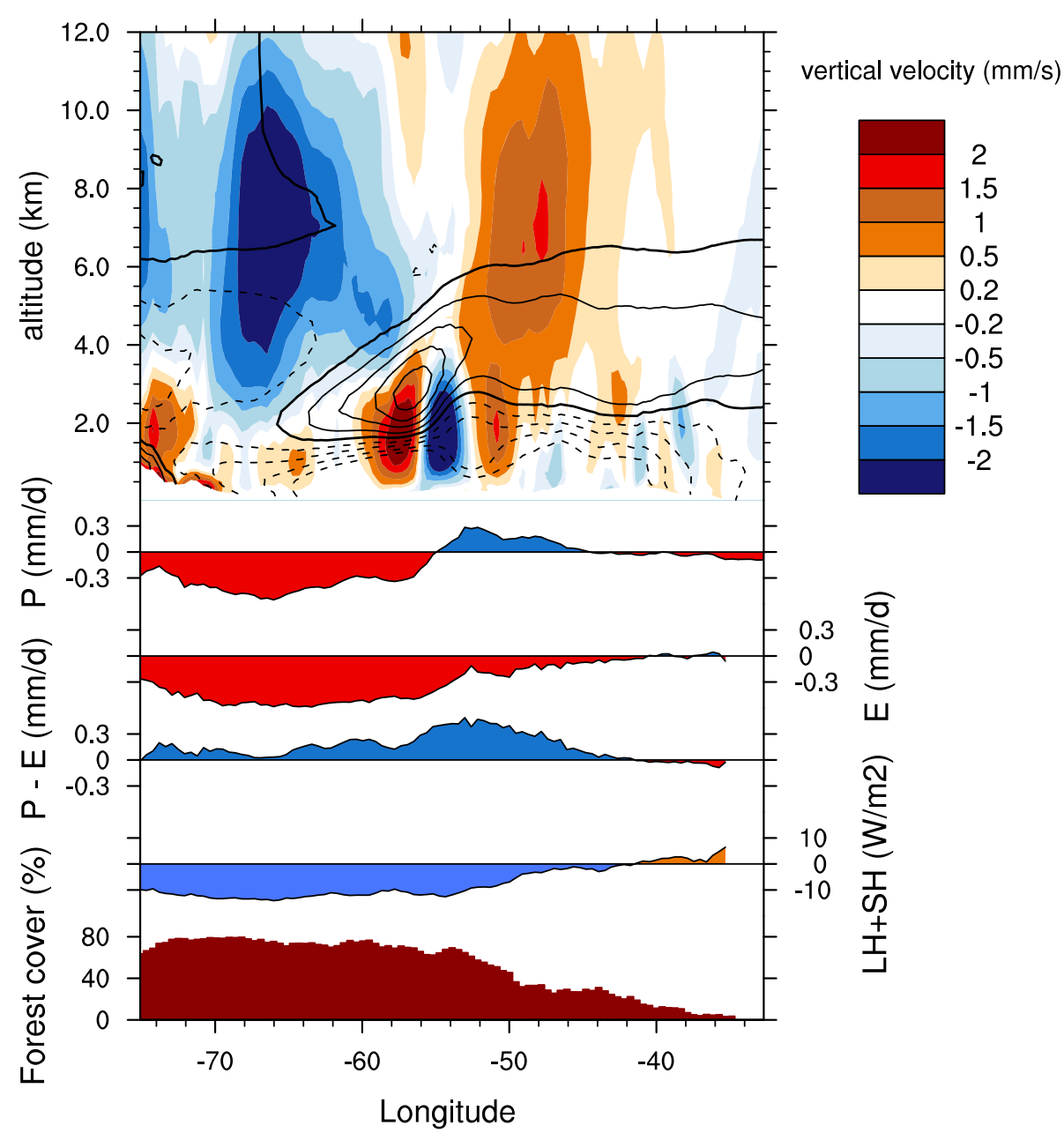

deforestation, as well as the good match between the patterns of deforestation and the resulting warming, indicate that changes in surface temperature are mostly driven by local effects. Nevertheless, part of the effect of deforestation-induced circulation changes on air temperature may be missing in our simulations, since we used an RCM with prescribed boundary conditions.

\subsubsection{Evolution of precipitation with deforestation}

On average over the Amazonian region, deforestation leads to a decrease in annual mean precipitation, although there are regional differences (Fig. 3b, d, f). On the one hand, west of the $55^{\circ} \mathrm{W}$ meridian, the Amazon basin is dominated by a decrease in annual mean precipitation in 
Fig. 6 Atmospheric moisture transport at $850 \mathrm{hPa}$ in CTL (a), and difference between DEF_TOT and CTL (b). Vector scale (upper-right corner of the maps) is $0.1\left(\mathrm{~kg} \mathrm{H}_{2} \mathrm{O} / \mathrm{kg}\right.$ air $)(\mathrm{m} /$ s) for (a), and $0.01\left(\mathrm{~kg} \mathrm{H}_{2} \mathrm{O} / \mathrm{kg}\right.$ air) $(\mathrm{m} / \mathrm{s})$ for $(\mathbf{b})$
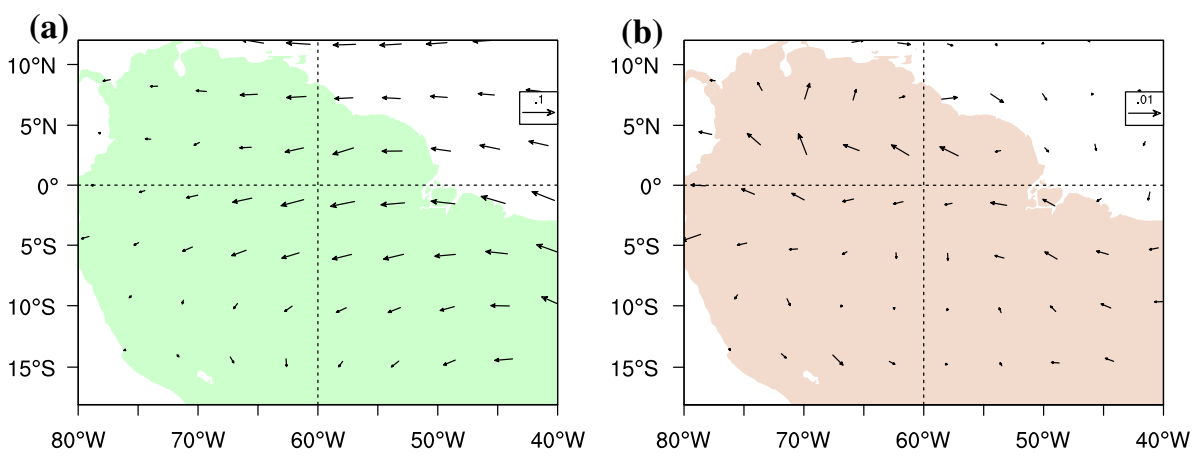

Fig. 7 Changes in annual mean surface temperature (a), precipitation (b), evaporation (c), and P-E (d) against percentage of deforestation, as simulated in this study and previous ones. Big light blue dots represent the results from the "oldest" GCM studies, and small dark blue ones those from the "newest" GCM studies (see Table 3). Small markers stand for the results from our study (black) or from two other series of RCM experiments (red, surface temperature changes are only available for one study, see Table 4). The $0 \%$ level of deforestation refers to presentday land cover (complete methodology is available in the Online Resource). The vertical bars show the range between the first and ninth deciles for the "oldest" (light blue bar) and the "newest" studies (black blue bar). The horizontal black lines inside each bar indicate the median for each category of models, while the numbers above or below the bars indicate how many models are included in each category

\section{Legend}

"oldest" GCM studies o "newest" GCM studies

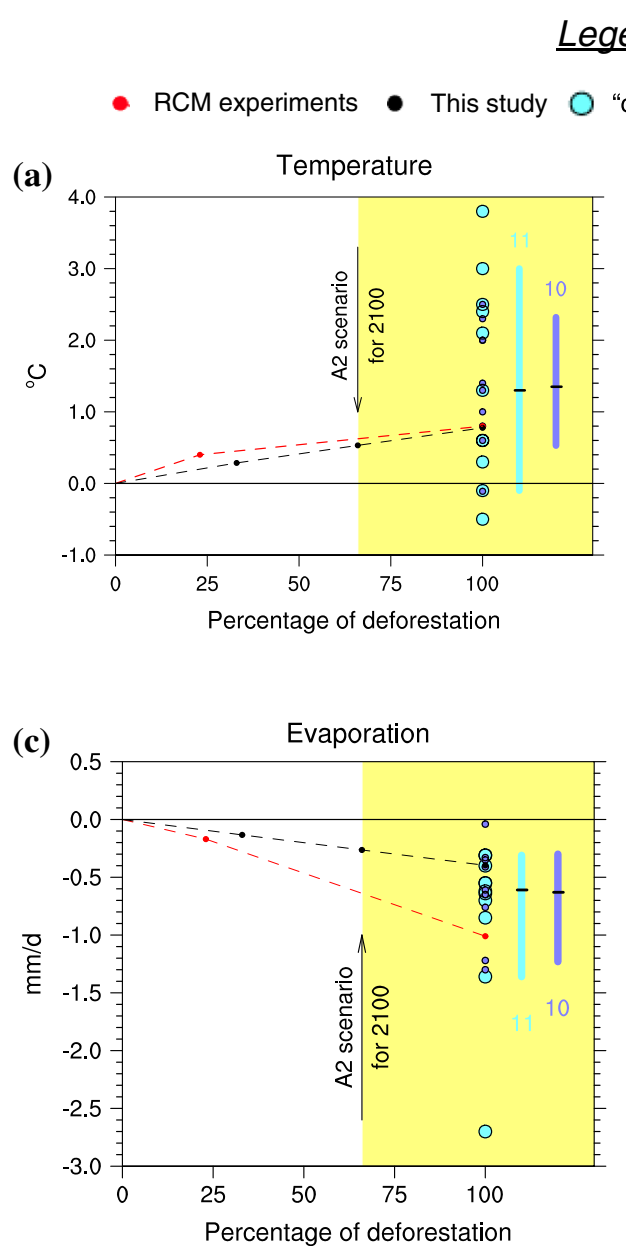

(a)

(c)

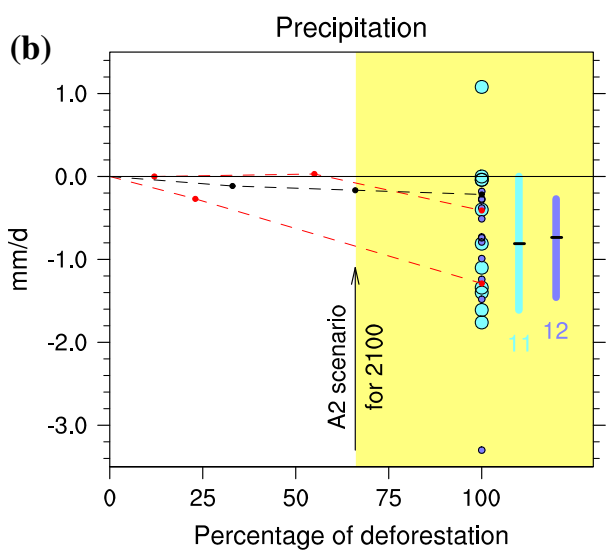

(d)

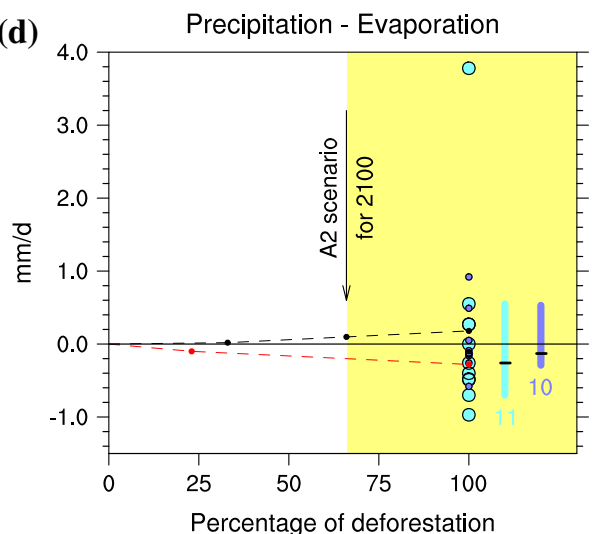

response to deforestation. On the other hand, the eastern edge of the rainforest and the Guianas experience a slight increase in precipitation, although deforestation also occurs there. Anomalies are statistically significant for specific seasons, particularly in DJF (not shown). This dipole pattern is found for all deforestation experiments, and increases with the extent of deforestation, which suggests that this is not due to random noise (Fig. 3).

The mean seasonal cycle of precipitation in Fig. $4 \mathrm{~b}$ shows that the most important decrease in precipitation occurs in the middle of the dry season, because this is the season when evapotranspiration is most reduced (June, July, August and September). Although the simulated reduction in annual mean rainfall remains small, these seasonal differences in the climate changes induced by deforestation, especially the higher impact during the dry season, are of importance for local ecosystems. It was indeed observed that they experienced lasting negative effects after the extremely severe dry seasons of years 2005 and 2010 (Samanta et al. 2010; Xu et al. 2011). 
The average diminution in mean precipitation over the Amazonian region becomes more important as deforestation progresses (Figs. 3, 4). These changes correspond to decreases of $2.7,4.1$ and $5.3 \%$ of mean precipitation. It is interesting to note that the mean rainfall change in DEF_50\% corresponds to half of that in DEF_TOT, although the amount of deforestation is three times lower. Thus, in our simulations the mean precipitation decrease curbs as deforestation progresses without reaching a tipping point, i.e a threshold after which it would drastically decrease in a strongly nonlinear way. To explain this result, we can separate the different contributions to precipitation within the Amazonian region into the local water input to the atmosphere through evapotranspiration, and the atmospheric moisture convergence into the region. We assume here that the atmospheric moisture content remains constant in all experiments, which is equivalent to considering that moisture convergence equals the difference between precipitation and evapotranspiration (hereafter referred to as $\mathrm{P}-\mathrm{E})$. This assumption is often made for climatic timescales, and we indeed found that changes in $\mathrm{P}-\mathrm{E}$ and atmospheric moisture convergence are very similar. As discussed in the previous section, average changes in evapotranspiration within the Amazonian basin are proportional to the amount of deforestation. However, this is not the case for changes in $\mathrm{P}-\mathrm{E}$, as it increases by $1.6 \%$ in DEF_50\%, $7.2 \%$ in DEF_A2 and $14.4 \%$ in DEF_TOT compared to CTL. This nonlinear evolution explains the tendency of the mean precipitation decrease to slightly curb as deforestation progresses.

\subsubsection{Mechanisms underlying the regional variations in the precipitation response}

Figure 5 displays a cross-section showing the changes in the annual mean of several variables in DEF_TOT compared to CTL, along a West-East transect across the Amazonian basin (shown in blue on Fig. 1a). The other deforestation experiments exhibit similar changes qualitatively, but of lower magnitude (not shown). The main feature we aim to understand in this section is the EastWest dipole pattern characterising the change in precipitation (2nd panel). The spatial pattern of changes in evapotranspiration (3rd panel) reflects relatively well the local deforestation rates (lower panel). Besides, over this same area the trees that are removed in the deforestation simulations mostly belong to the PFT broadleaf evergreen tropical tree, whose transpiration rates are similar to those of grasslands, contrary to the western part of the transect where most of the trees belong to the PFT broadleaf deciduous tropical tree, for which transpiration rates are higher. Amazonia has been shown to be a region of major precipitation recycling (e.g. van der Ent et al. 2010), where water is made available for precipitation locally and downwind through sustained evapotranspiration rates. In the western part of the Amazonian region, this mechanism is dampened because of the reduction in evapotranspiration. As moisture is mostly transported westward by westerlies over Amazonia (Fig. 6a), this drives the decrease in precipitation over the western part of the transect.

Unlike evapotranspiration, P-E increases over the deforested region (4th panel), which is related to changes in the atmospheric circulation. Deforestation induces a decrease in roughness length due to the replacement of trees by short vegetation. This reduces surface friction, and leads to an increase in wind speed in the lower atmosphere (upper panel in Fig. 5). Hence, the moisture transport from the ocean to the Amazonian region is increased by deforestation in our experiments (Fig. 6b).

We find that vertical velocity is decreased over the western part of the transect in our deforestation experiments (upper panel in Fig. 5), which indicates that deforestation induces subsidence over this region. This is mainly related to changes in surface heat fluxes: Over deforested areas, the albedo-induced decrease in surface net radiation lowers the overall amount of energy transmitted into the atmosphere. This means that less energy is available for convection, following the mechanism described by Eltahir (1996). However, this diminution of net radiation is maximal west of the $55^{\circ} \mathrm{W}$ meridian, whereas east of $50^{\circ} \mathrm{W}$ changes are roughly zero (5th panel in Fig. 5). Consequently, large-scale subsidence occurs over the western part of the transect. The surplus of moisture transport induced by the reduced surface friction is then mostly contributing to the increase in precipitation east of $\sim 55^{\circ} \mathrm{W}$, while its transport further west is dampened by the subsiding motion (as shown by the reduced horizontal wind velocities from $\sim 2$ to $6 \mathrm{~km}$ over the eastern part of the transect). This results in the creation of the dipole pattern. Furthermore, the peak in the rainfall increase (at $\sim 53^{\circ} \mathrm{W}$ ) coincides with a local diminution of the sensible heat flux (not shown), which is due to the albedo-driven decrease in net radiation, while the latent heat flux remains almost constant. Interestingly, in their two-month simulations of both partial and total deforestation, Ramos da Silva et al. (2008) observed a similar dipole pattern in the response of precipitation to deforestation, which was due to similar mechanisms.

To sum up, the spatial variations in the response of precipitation to deforestation are determined by both local effects (surface energy and water fluxes) and changes in regional atmospheric circulation. We, however, acknowledge that the use of an RCM may dampen possible circulation changes at large scale due to the prescribed lateral boundary conditions. This may in particular affect the 
changes in large-scale subsidence or convection which determine the simulated dipole pattern of precipitation. Since the response of moisture convergence also induces some non-linearity in the evolution of mean precipitation with deforestation in our experiments, it is hence interesting to compare our results to those of other similar previously published studies, using both RCMs or GCMs.

\section{Comparison with earlier modelling studies}

Our modelling results are compared here with results from 28 previously published deforestation experiments. Of these, 23 were performed with GCMs and are listed in Table 3, while the five others were conducted with RCMs and are listed in Table 4. In all studies the control simulation represents the current vegetation state, and the domain used for the computation of the reported average values covers an area whose size is comparable to that of the Amazonian rainforest, and which is centred over the deforested area. Furthermore, all experiments were conducted during at least 1 year, and with greenhouse gas concentrations fixed to present-day values. We compare the annual mean changes in surface temperature and precipitation obtained in these experiments against the percentage of deforestation they assumed in the Amazonian region (Fig. 7, see the Online Resource for a detailed description of the methodology).

These numerous reported experiments differ in many aspects, which are thus likely to induce spread between the obtained results. They were conducted with different models, employing different resolutions, different surface schemes, different simulation lengths, different representations of the land cover, etc. Their range of responses can thus be used to assess the current uncertainty in the regional climate response to deforestation, and whether some types of models exhibit a systematic tendency in their results (e.g. RCMs compared to GCMs, or latest model versions against older ones).

\subsection{Uncertainties in the effect of total deforestation and the influence of GCM development}

Most of the GCM studies reported on Fig. 7 (blue dots on the right of each graph) agree that complete deforestation over Amazonia would induce an increase in surface temperature (median $=1.3^{\circ} \mathrm{C}$ ) and a decrease in precipitation (median $=-0.74 \mathrm{~mm} /$ day) regionally (Fig. $7 \mathrm{a}, \mathrm{b}$ ), even if there is an important spread within the simulated changes. To assess whether the historical development of climate modelling has led to a change in the mean or the spread of the estimated regional changes, we differentiate between the 12 "newest" and the 11 "oldest" GCM studies considered here. This separation is partly based on the publication date, but because five groups of studies have been performed with different versions of the same models, we retained only the experiments which employed the latest version of these models among the "newest" studies (see Table 3 for the exact listing for each category).

For surface temperature, a non-parametric Wilcoxon test gives us $90 \%$ confidence that the medians of the estimates for the "newest" and "oldest" studies are not statistically different. The spread between the estimates of the "newest" studies is smaller than between those of the "oldest" studies, as highlighted by the range between the first and ninth deciles of each category $\left(3.1^{\circ} \mathrm{C}\right.$ for the oldest studies, $1.8^{\circ} \mathrm{C}$ for the newest) and confirmed by a Student's $t$ test and a non-parametric Wilcoxon test (Fig. S1 of the Online Resource). We note that this conclusion does not hold if we only consider the criterion of the publication date (see Fig. $\mathrm{S} 1$ of the Online Resource). However, the two GCM studies simulating the strongest increases in surface temperature (Polcher and Laval 1994a; Dickinson and Henderson-Sellers 1988), as well as two of the three studies simulating the strongest decreases (Manzi and Planton 1996; Voldoire and Royer 2004), have been followed by studies giving results closer to the median of all GCMs after inclusion of model improvements in the newest version of the respective GCMs (Polcher and Laval 1994b; Hahmann and Dickinson 1997; Voldoire and Royer 2005).

Regarding precipitation, a non-parametric Wilcoxon test reveals that the medians of the estimates for the "newest" and "oldest" studies are also not statistically different ( $p$ value $=0.88)$. The spread between the first and the ninth deciles is lower for the "newest" $(1.1 \mathrm{~mm} /$ day $)$ than for the "oldest" studies (1.6 mm/day). These conclusions are confirmed by a Student's $t$ test and a Wilcoxon test, and still hold if we only consider the criterion of the publication date (see Fig. S1 of the Online Resource). Furthermore, the only study simulating an increase in precipitation (Polcher and Laval 1994a), the two studies simulating the weakest decreases (Dickinson and Henderson-Sellers 1988; Manzi 1993), as well as four out of the six studies simulating the most extreme decreases in rainfall (Nobre et al. 1991; Henderson-Sellers et al. 1993; Dickinson and Kennedy 1992; Lean and Warrilow 1989) have been followed by studies using improved model versions and giving results closer to the model median (Polcher and Laval 1994b; Hahmann and Dickinson 1997; Voldoire and Royer 2005; Lean and Rowntree 1997).

This reduction in the spread of estimated temperature and precipitation changes can be partly related to a small reduction in the spread of the simulated changes in evapotranspiration $(0.93 \mathrm{~mm} /$ day for the "newest" studies, against $1.05 \mathrm{~mm} /$ day for the "oldest" ones, see also Fig. 7c). There is strong agreement among the reported GCM studies that deforestation will entail a reduction in evapotranspiration, 


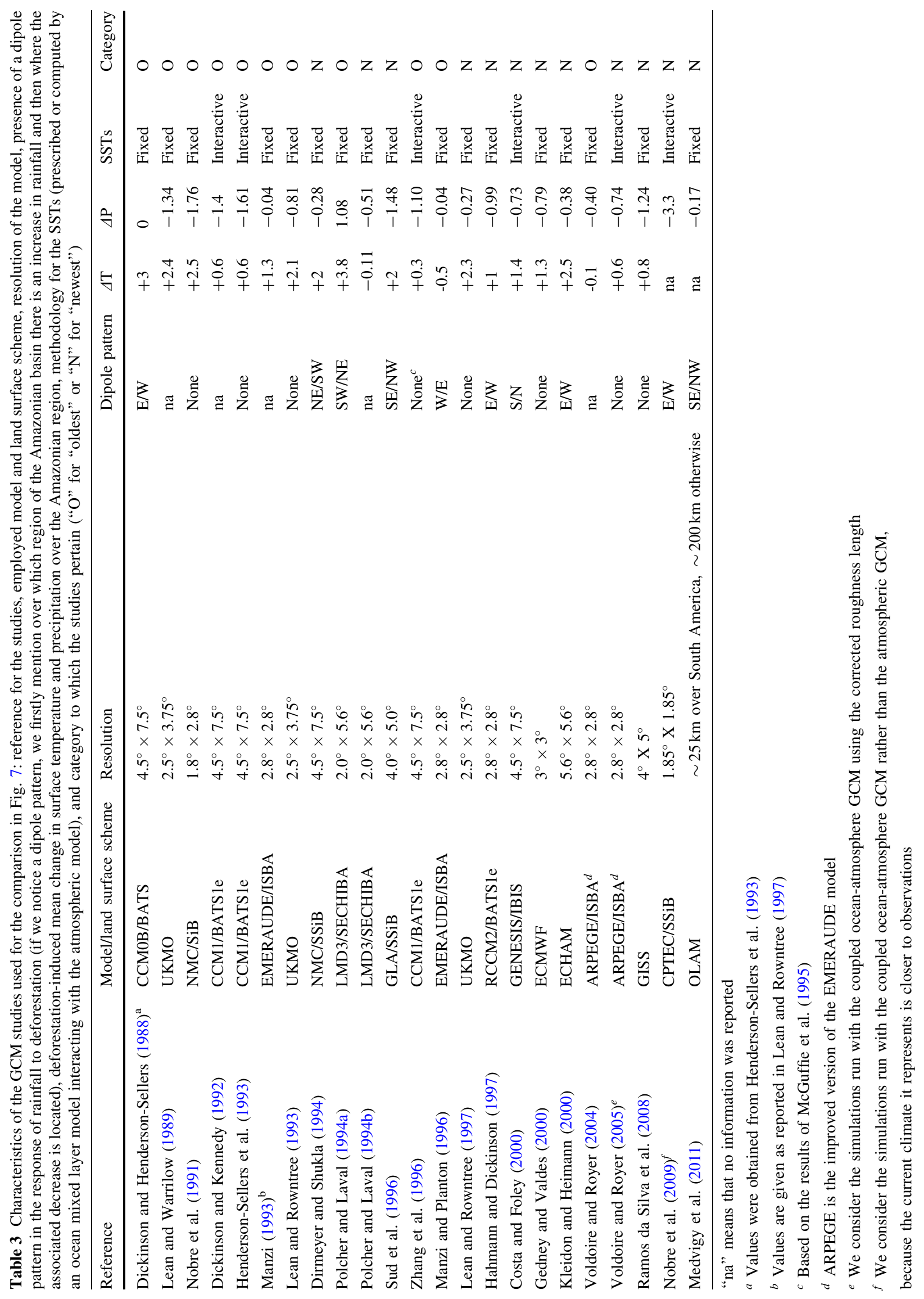


with a median decrease of $\sim 0.6 \mathrm{~mm} /$ day for both "oldest" and "newest" studies. Even more striking is the reduction in the spread of the changes in moisture convergence, which is more than three times more important (from 1.25 for the "oldest" studies to $0.82 \mathrm{~mm} /$ day for the "newest" ones, see also Fig. 7d). The better agreement in the newest GCMs concerning the magnitude of the mean precipitation decrease is therefore mostly due to a closest agreement in terms of moisture convergence and circulation changes following deforestation. This result is confirmed by a Student's $t$ test and a Wilcoxon test. That said, even the "newest" studies do not agree on the sign of the change in moisture convergence, and both "oldest" and "newest" studies indicate a median decrease in P-E which is not statistically different.

Overall, these results suggest that improvements in climate models have reduced the range of biogeophysical responses to Amazonian deforestation, and thus indicate that the most extreme estimates (increase of temperature by more than $2.5^{\circ} \mathrm{C}$ or decrease of temperature, decrease of precipitation by more than $1.5 \mathrm{~mm} /$ day or increase of precipitation) are very unlikely. However, the sign of the changes in moisture convergence, which induce some nonlinearity in the precipitation response in our experiments, still remains uncertain.

\subsection{Evolution of the climate impacts with the extent} of deforestation according to RCM experiments

Figure 7 also shows the evolution of the biogeophysical effect of deforestation as a function of the deforestation rate in different RCM experiments (black and red dots). The results reported in the left part of each graph (left in white) were obtained in response to percentages of deforestation lower or equal to the estimate of the A2 scenario for 2100 used in this study, and therefore represent changes which could occur during the twenty-first century.

Our results and those from Correia et al. (2008) agree that the biogeophysical effects of Amazonian deforestation would induce an increase in annual mean surface temperature on average over Amazonia. This warming is limited to $0.6^{\circ} \mathrm{C}$ during the twenty-first century, and to $0.8^{\circ} \mathrm{C}$ in case of total deforestation. Yet, Correia et al. (2008) found that the increase of surface temperature with the extent of deforestation departs from the linear behaviour observed in our simulations (Fig. 7a).

We report three RCM studies which give estimates of changes in precipitation following deforestation, including ours. They agree on the fact that deforestation would not entail an increase in mean precipitation over Amazonia. They suggest a decrease in mean rainfall ranging from 0 to $0.85 \mathrm{~mm} /$ day by 2100 , and from 0.2 to $1.3 \mathrm{~mm} /$ day in response to total deforestation $(\sim 5-10 \%$, excluding Correia et al. (2008) where relative changes were not available, see also Fig. S2 of the Online Resource). The shape of the evolution of mean precipitation with the extent of deforestation is model-dependent (Fig. 7b): It curbs in our simulations, it is linear in Correia et al. (2008), while it remains rather insensitive until the threshold of $55 \%$ is reached in Walker et al. (2009), after which it declines more quickly. Contrary to our simulations, Correia et al. (2008) find a decrease in moisture convergence following deforestation, but this response exhibits a nonlinear behaviour as well (Fig. 7d).

Note, however, that the already mentioned tipping point might be more likely to occur in the context of enhanced greenhouse gas forcing (Malhi et al. 2008; Cox et al. 2004), for which some (but not all) GCMs project an increase of drought conditions in the Amazon (e.g. Seneviratne et al. 2012; Orlowsky and Seneviratne 2012, 2013). Besides, the global warming signal, not considered in these studies, will likely dominate the changes in surface temperature over the Amazonian basin during the twenty-first century (Costa and Foley 2000). Furthermore, the limited number of RCM experiments reported here prevents us from drawing clear conclusions at this stage. Together with the possibly lacking representation of large-scale circulation feedbacks in RCMs, this highlights the need for a comparison of the large available number of GCM studies to better assess uncertainties about the climate response to deforestation, as presented in Sect. 4.1.

\subsection{Impacts of missing large-scale feedbacks in RCMs} on their estimation of the climate response to deforestation

The three RCM experiments of total deforestation (including ours) reported in Fig. 7b simulate decreases in rainfall over Amazonia. Compared to GCM estimates, these decreases are approximately equal to the 25th and 75th percentiles of the range of GCM studies. When seen in terms of relative changes, our RCM experiment and that of Moore et al. (2007) (values were not available for Correia et al. 2008) are even closer to the median of GCM studies (Fig. S2 of the Online Resource). Although RCMs and GCMs differ in terms of their representation of large-scale atmospheric feedbacks, which might lead to differences in the simulated sensitivity to deforestation, this analysis does not support the hypothesis of a systematically different sensitivity to Amazonian deforestation in RCM studies compared to GCM studies because (1) existing RCM estimates lie within the range of GCM estimates and (2) there is still too few RCM studies available to statistically identify systematic differences between RCM and GCM estimates. This contradicts the earlier suggestion by Medvigy et al (2011) who noted, based on a smaller number of RCM and GCM studies, that RCMs generally 
simulate a smaller response of precipitation to deforestation compared to GCMs. We note however that a direct comparison between a GCM and a RCM including the same physical parameterisations would be necessary to strictly disentangle the possible role of missing large-scale feedbacks in RCMs.

As for oceanic feedbacks, only six from the 23 reported GCM studies implemented an ocean mixed layer. They simulated a median decrease in rainfall almost twice higher $(-1.36 \mathrm{~mm} /$ day $)$ than the median of all GCM studies, but a twice-lower median surface warming $\left(+0.6^{\circ} \mathrm{C}\right)$. In particular, Nobre et al. (2009) ran simulations both with and without an interactive ocean, and found a $60 \%$ higher rainfall reduction in the first configuration than in the second one. However, with the same protocol but a different model Voldoire and Royer (2005) found similar results with both configurations, which shows that the importance of oceanic feedbacks remains very uncertain. Still, the inability to take these feedbacks into account constitutes a limitation of RCMs.

\subsection{Regional variations in the impact of deforestation} on rainfall within the Amazonian basin

We already mentioned that, similarly to our experiments, Ramos da Silva et al. (2008) found that changes in precipitation induced by deforestation are not monotonic over Amazonia, but rather follow a dipole pattern closely linked to the response of surface energy fluxes. This pattern is reinforced for higher percentages of deforestation, but may be partly due to the prescribed atmospheric boundary conditions. In Tables 3 and 4 , we make an inventory of other modelling studies that found such a pattern in the response of rainfall to deforestation-in a qualitative way-and precise its orientation. We estimate that a bimodal pattern is simulated in 12 of the 23 experiments for which maps of the deforestation-induced changes in precipitation are shown (including 10 GCM experiments), while for four studies (including three GCM ones), its orientation is the same as in our experiments. This shows that even if we expect precipitation to decrease on average over Amazonia in response to deforestation, about half of the studies that provide information on the spatial pattern of these changes indicate that there should be high geographical variability in these trends within the Amazonian basin. This is of particular importance if one wants to study the impacts of these deforestation-induced changes in precipitation on local ecosystems. It also highlights the importance of using mesoscale resolutions and state-of-the-art land surface schemes for that purpose. These are required to finely represent the forthcoming deforestation pattern and

presence of a dipole pattern in the response of rainfall to deforestation, and deforestation-induced mean change in surface temperature and precipitation over the Amazonian region comparison in Fig. 7: reference for the studies, percentage of deforestation in the performed experiment, employed resolution, simulation domain, simulation time and boundary conditions,

\begin{tabular}{|c|c|c|c|c|c|c|c|}
\hline Reference & $\begin{array}{l}\text { Percentage of } \\
\text { deforestation }\end{array}$ & Resolution & $\begin{array}{l}\text { Simulation } \\
\text { domain }\end{array}$ & $\begin{array}{l}\text { Simulation time }{ }^{a} \text { (boundary } \\
\text { conditions) }\end{array}$ & $\begin{array}{l}\text { dipole } \\
\text { pattern }\end{array}$ & $\Delta \mathrm{T}$ & $\Delta \mathrm{P}$ \\
\hline $\begin{array}{l}\text { Moore et al. } \\
(2007)^{\mathrm{b}}\end{array}$ & 12 & $\sim 20 \mathrm{~km}$ & Amazon basin & $5 \times 12$ months $^{c}(1997-2001)$ & None & na & $0^{d}$ \\
\hline $\begin{array}{l}\text { Moore et al. } \\
(2007)^{b}\end{array}$ & 100 & $\sim 20 \mathrm{~km}$ & Amazon basin & $5 \times 12$ months $^{c}(1997-2001)$ & None & na & $-0.41^{\mathrm{d}}$ \\
\hline $\begin{array}{l}\text { Walker et al. } \\
(2009)^{\mathrm{b}}\end{array}$ & 55 & $\sim 20 \mathrm{~km}$ & Amazon basin & $5 \times 12$ months $^{c}(1997-2001)$ & $\mathrm{SE} / \mathrm{NW}$ & na & $+0.03^{d}$ \\
\hline $\begin{array}{l}\text { Correia et al. } \\
\text { (2008) }\end{array}$ & 23 & $\sim 40 \mathrm{~km}$ & South America & 12 months $(2000)$ & NE/SW & +0.4 & -0.27 \\
\hline $\begin{array}{l}\text { Correia et al. } \\
(2008)\end{array}$ & 100 & $\sim 40 \mathrm{~km}$ & South America & 12 months $(2000)$ & None & +0.8 & -1.29 \\
\hline This study & 33 & $0.44^{\circ}$ & South America & 24 years $(1987-2010)$ & $\mathrm{E} / \mathrm{W}$ & 0.36 & -0.11 \\
\hline This study & 66 & $0.44^{\circ}$ & South America & 24 years $(1987-2010)$ & $\mathrm{E} / \mathrm{W}$ & 0.61 & -0.17 \\
\hline This study & 100 & $0.44^{\circ}$ & South America & 24 years $(1987-2010)$ & $\mathrm{E} / \mathrm{W}$ & 0.75 & -0.22 \\
\hline
\end{tabular}

If we notice a dipole pattern, we firstly precise over which region of the Amazonian basin there is an increase in rainfall, and then where the associated decrease is located

${ }^{a}$ Spin-up time excluded

${ }^{b}$ Simulation of Moore et al. (2007) and Walker et al. (2009) only differ in terms

of vegetation maps, and are hence considered as only one experiment in Fig. 7

${ }^{c}$ The different 12-month periods were simulated in different runs

${ }^{d}$ Values are adapted from the Fig. 3 of Walker et al. (2009) 
resulting climatic changes, as well as the mechanisms underlying them through a correct description of surface energy fluxes.

\section{Conclusion}

Using an RCM coupled to a state-of-the-art land surface model (COSMO-CLM ${ }^{2}$ ), we ran four simulations of 32 years each at a resolution of $50 \mathrm{~km}$ over South America. Each run differed only in terms of the prescribed land cover maps, in order to investigate the biogeophysical effects of possible future deforestation on the Amazonian climate. A control experiment was run using a land-cover map representative of present-day vegetation distribution. Two deforestation experiments were forced by maps reproducing two scenarios of LULCC of different intensity that may both occur before the end of the twenty-first century, while another one considered a totally deforested Amazon. We find that COSMO-CLM ${ }^{2}$ shows non-negligible biases, but its performance over this region is very similar to that of other state-of-the-art RCMs.

Results show that by year 2100, prescribed LULCC would induce a surface temperature increase of $0.5^{\circ} \mathrm{C}$ on average over the Amazonian region, compared to present conditions. The warming is higher over areas experiencing the strongest rates of deforestation, where it can reach $+2{ }^{\circ} \mathrm{C}$ at the end of the dry season, because shallow-rooted grasses cannot take up water in the deep soil water reservoirs. The hydrological cycle is also perturbed by these LULCC. On average over the Amazonian basin, we find an average decrease in precipitation of $0.17 \mathrm{~mm} /$ day. This diminution in precipitation is highest during the summer and winter seasons. In our total deforestation simulation, the LULCC-induced annual mean surface warming reaches $0.8^{\circ} \mathrm{C}$, while the decrease in precipitation is as high as 0.22 $\mathrm{mm} /$ day. While we find that surface temperature increases linearly as deforestation progresses, this is not the case for precipitation, because of the nonlinear response of moisture convergence into the Amazonian region. Besides, the mean decrease in precipitation hides the fact that there is a redistribution in rainfall amounts within the region, with central and western Amazon getting drier and eastern Amazon getting wetter. This results from regional variations in the changes of surface energy and water fluxes, which lead to a reorganisation of the large-scale circulation.

We then analysed the results from 28 previously published deforestation experiments conducted with a GCM or an RCM. Overall, the set of studies we looked at suggests that deforestation within the twenty-first century, independently of the effects of greenhouse gas forcing on climate, will lead to an increase in annual mean surface temperature by no more than $0.6^{\circ} \mathrm{C}$ on average over the Amazonian region, while a median estimate for the warming following total deforestation is $1.3{ }^{\circ} \mathrm{C}$. However, the estimates for the decrease in average precipitation by 2100 range from 0 to $-0.85 \mathrm{~mm} /$ day $(\sim-5-10 \%)$, whereas a median estimate in case of total deforestation reaches $-0.75 \mathrm{~mm} /$ day. In our simulations, we find that the average changes in surface temperature and precipitation over the Amazonian region lie within the range of those obtained by other studies investigating the effects of comparable scenarios of deforestation. This comparative analysis also reveals that historical developments in modelling have decreased the uncertainty in the simulated climate response to total deforestation by GCMs. Hence, studies using the most recent version of a model generally simulate changes that are closer to the median of the whole sample of GCM studies than those using older versions of the same model. This emphasises the further needs for model improvements in order to better assess the effects of LULCC on the climate system. RCMs may fail to fully capture the large-scale circulation feedbacks induced by LULCC, but contrary to what has been previously suggested, and even if only a few RCM studies investigating the effect of total deforestation have been conducted, the reported RCM experiments do not systematically show a lower sensitivity to Amazonian deforestation than GCM studies. However, this might have been the case if all GCM experiments had accounted for oceanic feedbacks, which were shown to amplify the response to deforestation in some studies, but cannot be taken into account in an RCM.

The dipole pattern in the precipitation response to deforestation was already obtained in previous studies, emphasising that deforestation will likely entail regional differences in the trends in rainfall within the Amazonian basin. The shape of the evolution of precipitation with deforestation is model-dependent, but only one out of three studies suggests that a tipping point after which mean rainfall amounts would nonlinearly decline will be reached, though with limited impacts. It is important to note that these estimates do not consider concomitant effects of enhanced greenhouse gas forcing, nor possible interactions and amplifications between greenhouse-gas and deforestation-induced effects. Besides, the large-scale feedbacks following deforestation may be incompletely represented in these RCM studies. Nonetheless, although this needs to be confirmed by further model simulations, our RCM experiments as well as the conducted survey of the literature suggest that recent climate models simulate a more consistent biogeophysical response to Amazonian deforestation than earlier climate models, and that extreme scenarios related to the presence of tipping points from 
biogeophysical effects alone in the absence of greenhouse gas forcing are rather unlikely.

Acknowledgments This study was partially supported by the EUFP7 EMBRACE project. Computing time was provided by the Swiss National Supercomputing Centre (CSCS). We are particularly thankful to Anne Roches for technical support and Lukas Gudmundsson for his advice regarding statistics, as well as Silvina Solman for helpful discussions.

Open Access This article is distributed under the terms of the Creative Commons Attribution License which permits any use, distribution, and reproduction in any medium, provided the original author(s) and the source are credited.

\section{References}

Achard F, Eva HD, Stibig HJ, Mayaux P, Gallego J, Richards T, Malingreau JP (2002) Determination of deforestation rates of the world's humid tropical forests. Science 297(5583):999-1002. doi:10.1126/science.1070656

Avissar R, Dias PLS, Dias MAFS, Nobre C (2002) The large-scale biosphere-atmosphere experiment in Amazonia (LBA): insights and future research needs. J Geophys Res 107(D20):8086. doi:10.1029/2002JD002704

Bonan G (2008) Forests and climate change: forcings, feedbacks, and the climate benefits of forests. Science 320(5882):1444-1449. doi:10.1126/science. 1155121

Correia F, Alvalá R, Manzi A (2008) Modeling the impacts of land cover change in Amazonia: a regional climate model (RCM) simulation study. Theor Appl Climatol 93(3-4):225-244. doi:10. 1007/s00704-007-0335-z

Costa MH, Foley JA (2000) Combined effects of deforestation and doubled atmospheric $\mathrm{CO}_{2}$ concentrations on the climate of Amazonia. J Clim 13:18-34

Cox PM, Betts RA, Collins M, Harris PP, Huntingford C, Jones CD (2004) Amazonian forest dieback under climate-carbon cycle projections for the 21 st century. Theor Appl Climatol 78(1-3):137-156. doi:10.1007/s00704-004-0049-4

Dai A (2006) Precipitation characteristics in eighteen coupled climate models. J Clim 19(18):4605-4630

d'Almeida C, Vörösmarty CJ, Hurtt GC, Marengo JA, Dingman SL, Keim BD (2007) The effects of deforestation on the hydrological cycle in Amazonia: a review on scale and resolution. Int $\mathbf{J}$ Climatol 27(5):633-647. doi:10.1002/joc.1475

Davin E, Noblet-Ducoudré N (2010) Climatic impact of global-scale deforestation: radiative versus non-radiative processes. J Clim 23:97-112

Davin EL, Seneviratne SI (2012) Role of land surface processes and diffuse/direct radiation partitioning in simulating the European climate. Biogeosciences 9:1695-1707. doi:10.5194/bg-9-16952012

Davin EL, Stöckli R, Jaeger EB, Levis S, Seneviratne SI (2011) COSMO-CLM $^{2}$ : a new version of the COSMO-CLM model coupled to the community land model. Clim Dyn 37:1889-1907. doi:10.1007/s00382-011-1019-z

Dee DP, Uppala SM, Simmons AJ, Berrisford P, Poli P, Kobayashi S, Andrae U, Balmaseda MA, Balsamo G, Bauer P, Bechtold P, Beljaars ACM, van de Berg L, Bidlot J, Bormann N, Delsol C, Dragani R, Fuentes M, Geer AJ, Haimberger L, Healy SB, Hersbach H, Hólm EV, Isaksen L, Kålberg P, Köhler M, Matricardi M, McNally AP, Monge-Sanz BM, Morcrette JJ, Park
BK, Peubey C, de Rosnay P, Tavolato C, Thépaut JN, Vitart F (2011) The ERA-Interim reanalysis: configuration and performance of the data assimilation system. Q J R Meteorol Soc 137(656):553-597. doi:10.1002/qj.828

Dickinson RE, Henderson-Sellers A (1988) Modelling tropical deforestation: a study of GCM land-surface parametrizations. Q J R Meteorol Soc 114(480):439-462. doi:10.1002/qj. 49711448009

Dickinson RE, Kennedy P (1992) Impacts on regional climate of Amazon deforestation. Geophys Res Lett 19(19):1947-1950. doi:10.1029/92GL01905

Dirmeyer PA, Shukla J (1994) Albedo as a modulator of climate response to tropical deforestation. J Geophys Res 99(D10):20,863-20,877. doi:10.1029/94JD01311

Eltahir E (1996) Role of vegetation in sustaining large-scale atmospheric circulations in the tropics. J Geophys Res 101(D2):4255-4268

Eltahir EAB, Bras RL (1993) On the response of the tropical atmosphere to large-scale deforestation. Q J R Meteorol Soc 119(512):779-793. doi:10.1002/qj.49711951209

van der Ent RJ, Savenije HHG, Schaefli B, Steele-Dunne SC (2010) Origin and fate of atmospheric moisture over continents. Water Resour Res 46. doi:10.1029/2010WR009127

Fan Y, Miguez-Macho G (2010) Potential groundwater contribution to Amazon evapotranspiration. Hydrol Earth Syst Sci 14:2039-2056. doi:10.5194/hess-14-2039-2010

Fearnside P (2005) Deforestation in Brazilian Amazonia: history, rates, and consequences. Conserv Biol 19(3):680-688

Gedney N, Valdes PJ (2000) The effect of Amazonian deforestation on the northern hemisphere circulation and climate. Geophys Res Lett 27(19):3053-3056. doi:10.1029/2000GL011794

Greco S, Swap R, Garstang M, Ulaski S, Shipham M, Harriss RC, Talbot R, Andreae MO, Artaxo P (1990) Rainfall and surface kinematic conditions over central Amazonia during ABLE 2B. J Geophys Res Atmospheres 95(D10):17,001-17,014. doi:10. 1029/JD095iD10p17001

Hahmann AN, Dickinson RE (1997) RCCM2-BATS model over tropical South America: applications to tropical deforestation. J Clim 10(8):1944-1964

Hansen MC, DeFries RS, Townshend JRG, Caroll M, Dimiceli C, Sohlberg RA (2003) Global percent tree cover at a spatial resolution of 500 meters: first results of the MODIS vegetation continuous Fields Algorithm. Earth Interact 7(10):1-15

Henderson-Sellers A, Dickinson RE, Durbridge T, Kennedy P, McGuffie K, Pitman A (1993) Tropical deforestation: modeling local- to regional-scale climate change. J Geophys Res Atmospheres 98(D4):7289-7315. doi:10.1029/2JD02830

IMAGE team (2001) The IMAGE 2.2 implementation of the SRES scenarios: a comprehensive analysis of emissions, climate change and impacts in the 21st century. RIVM CD-ROM Publication 481508019, National Institute of Public Health and the Environment, Bilthoven

Jipp PH, Nepstad DC, Cassel DK, de Carvalho CR (1998) Deep soil moisture storage and transpiration in forests and pastures of seasonally dry amazonia. Clim Change 39:395-412

Joetzer E, Douville H, Delire C, Ciais P (2013) Present-day and future Amazonian precipitation in global climate models: CMIP5 versus CMIP3. Clim Dyn 41(11-12):2921-2936. doi:10.1007/ s00382-012-1644-1

Kleidon A, Heimann M (2000) Assessing the role of deep rooted vegetation in the climate system with model simulations: mechanism, comparison to observations and implications for Amazonian deforestation. Clim Dyn 16(2-3):183-199

Koster RD, Suarez MJ, Heiser M (2010) Variance and predictability of precipitation at seasonal-to-interannual timescales. Geophys Res Lett 1(1):26-46 
Lawrence DM, Oleson KW, Flanner MG, Thornton PE, Swenson SC, Lawrence PJ, Zeng X, Yang Z-L, Levis S, Sakaguchi K, Bonan GB, Slater AG (2011) Parameterization improvements and functional and structural advances in version 4 of the community land model. J Adv Model Earth Syst 3:M03001. doi:10.1029/ 2011MS000045

Lawrence PJ, Chase TN (2007) Representing a new MODIS consistent land surface in the Community Land Model (CLM 3.0). J Geophys Res Biogeosci 112(G1). doi:10.1029/ 2006JG000168

Lean J, Rowntree P (1993) A GCM simulation of the impact of Amazonian deforestation on climate using an improved canopy representation. Q J R Meteorol Soc 119(511):509-530. doi:10. 1002/qj.497119,51109

Lean J, Rowntree P (1997) Understanding the sensitivity of a GCM simulation of Amazonian deforestation to the specification of vegetation and soil characteristics. J Clim 10(6):1216-1235

Lean J, Warrilow D (1989) Simulation of the regional climatic impact of Amazon deforestation. Nature 342:411-413. doi:10.1038/ $342411 \mathrm{a} 0$

Lorenz R, Davin EL, Seneviratne SI (2012) Modeling land-climate coupling in Europe: impact of land surface representation on climate variability and extremes. J Geophys Res Atmospheres 117(D20). doi:10.1029/2012JD017755

Lorenz R, Davin EL, Lawrence DM, Stöckli R, Seneviratne SI (2013) How important is vegetation phenology for european climate and heat waves? J Clim 26(24):10,077-10,100

Malhi Y, Roberts JT, Betts RA, Killeen TJ, Li W, Nobre CA (2008) Climate change, deforestation, and the fate of the Amazon. Science 319(5860):169-172. doi:10.1126/science.1146961

Manzi AO, Planton S (1996) Calibration of a GCM using ABRACOS and ARME data and simulation of Amazonian deforestation. In: Gash JHC, Nobre CA, Roberts JM, Victoria RL (eds) Amazonian deforestation and climate. Wiley, West Sussex, pp 505-530

Manzi O (1993) Introduction d'un schéma des transferts solvégétation-atmosphère dans un modèle de circulation générale et application à la déforestation Amazonienne. $\mathrm{PhD}$ thesis, Université Paul Sabatier, Toulouse

Marengo J (2006) On the hydrological cycle of the Amazonian basin: a historical review and current state-of-the-art. Rev Bras Meteor 21(3a):1-19

McGuffie K, Henderson-Sellers A, Zhang H, Durbidge TB, Pitman AJ (1995) Global climate sensitivity to tropical deforestation. Glob Planet Change 10(1-4):97-128. doi:10.1016/09218181(94)00022-6

Medvigy D, Walko RL, Avissar R (2011) Effects of deforestation on spatiotemporal distributions of precipitation in South America. J Clim 24(8):2147-2163

Mellor GL, Yamada T (1974) A hierarchy of turbulence closure models for planetary boundary layers. J Atmospheric Sci 31(7):1791-1806

Mellor GL, Yamada T (1982) Development of a turbulence closure model for geophysical fluid problems. Rev Geophys 20(4):851-875. doi:10.1029/RG020i004p00851

Mitchell TD, Jones PD (2005) An improved method of constructing a database of monthly climate observations and associated highresolution grids. Int J Climatol 25(6):693-712. doi:10.1002/joc. 1181

Moore N, Arima E, Walker R, da Silva RR (2007) Uncertainty and the changing hydroclimatology of the Amazon. Geophys Res Lett 34(14). doi:10.1029/2007GL030157

Nakicenovic N, Alcamo J, Davis G, de Vries B, Fenhann J, Gaffin S, Gregory K, Grübler A, Jung TY, Kram T, La Rovere EL, Michaelis L, Mori S, Morita T, Pepper W, Pitcher H, Price L, Riahi K, Roehrl A, Rogner HH, Sankovski A, Schlesinger M, Shukla P, Smith S, Swart R, van Rooijen S, Victor N, Dadi Z
(2000) Special report on emission scenarios. Cambridge University Press, Cambridge $599 \mathrm{pp}$

de Noblet-Ducoudré N, Boisier JP, Pitman A, Bonan GB, Brovkin V, Cruz F, Delire C, Gayler V, van der Hurk BJJM, Lawrence PJ, van der Molen MK, Müller C, Reick CH, Strengers BJ, Voldoire A (2012) Determining robust impacts of land-use-induced land cover changes on surface climate over North America and Eurasia: results from the first set of LUCID experiments. J Clim 25(9):3261-3281

Nobre CA, Sellers P, Shukla J (1991) Amazonian deforestation and regional climate change. J Clim 4(10):957-988

Nobre P, Malagutti M, Urbano DF, de Almeida RAF, Giarolla E (2009) Amazon deforestation and climate change in a coupled model simulation. J Clim 22(21):5686-5697

Oleson KW, Niu GY, Yang ZL, Lawrence DM, Thornton PE, Lawrence PJ, Stöckli R, Dickinson RE, Bonan GB, Levis S, Dai A, Qiance $T$ (2008) Improvements to the Community Land Model and their impact on the hydrological cycle. J Geophys Res 113(G1). doi:10.1029/2007JG000563

Orlowsky B, Seneviratne SI (2012) Global changes in extreme events: regional and seasonal dimension. Clim Change 110(3-4):669-696. doi:10.1007/s10584-011-0122-9

Orlowsky B, Seneviratne SI (2013) Elusive drought: uncertainty in observed trends and short- and long-term CMIP5 projections. Hydrol Earth Syst Sci 17:1765-1781. doi:10.5194/hess-17-17652013

Polcher J, Laval K (1994a) The impact of African and Amazonian deforestation on tropical climate. J Hydrol 155(3-4):389-405. doi:10.1016/0022-1694(94)90179-1

Polcher J, Laval K (1994b) A statistical study of the regional impact of deforestation on climate using the LMD GCM. Clim Dyn 10(4-5):205-219

Pongratz J, Reick CH, Raddatz T, Claussen M (2010) Biogeophysical versus biogeochemical climate response to historical anthropogenic land cover change. Geophys Res Lett 37(8). doi:10.1029/ 2010GL043010

Ramankutty N, Foley JA (1999) Estimating historical changes in global land cover: croplands from 1700 to 1992. Global Biogeochem Cycles 13(4):997-1027

Ramos da Silva R, Werth D, Avissar R (2008) Regional impacts of future land-cover changes on the Amazon Basin wet-season climate. J Clim 21(6):1153-1170. doi:10.1175/2007JCLI1304.1

Randall DA, Wood RA, Bony S, Colman R, Fichefet T, Fyfe J, Kattsov V, Pitman A, Shukla J, Srinivasan J, Stouffer RJ, Sumi A, Taylor KE (2007) Climate models and their evaluation. In: Solomon S, Qin D, Manning M, Chen Z, Marquis M, Averyt KB, Tignor $M$ and Miller HL (eds) Climate change 2007: the physical science basis. Contribution of Working Group I to the Fourth Assessment Report of the Intergovernmental Panel on Climate Change. Cambridge University Press, Cambridge

von Randow C, Manzi AO, Kruijt B, de Oliveira PJ, Zanchi FB, Silva RL, Hodnett MG, Gash JHC, Elbers JA, Waterloo MJ, Cardoso FL, Kabat P (2004) Comparative measurement and seasonal variability in energy and carbon exchange over forest and pasture in South West Amazonia. Theor Appl Climatol 78(1-3):5-26. doi:10.1007/s00704-004-0041-z

Samanta A, Ganguly S, Hashimoto H, Devadiga S, Vermote E, Knyazikhin Y, Nemani RR, Myneni RB (2010) Amazon forests did not green-up during the 2005 drought. Geophys Res Lett 37(5). doi:10.1029/2009GL042154

Seneviratne SI, Corti T, Davin EL, Hirschi M, Jaeger EB, Lehner I, Orlowsky B, Teuling AJ (2010) Investigating soil moistureclimate interactions in a changing climate: a review. Earth Sci Rev 99(3-4):125-161

Seneviratne SI, Nicholls N, Easterling D, Goodess CM, Kanae S, Kossin J, Luo Y, Marengo J, McInnes K, Rahimi M, Reichstein 
M, Sorteberg A, Vera C, Zhang X (2012) Changes in climate extremes and their impacts on the natural physical environment. In: Field CB, Barros V, Stocker TF, Qin D, Dokken DJ, Elbi KL, Mastrandrea MD, Mach KJ, Plattner G-K, Allen SK, Tignor M and Midgley PM (eds) Managing the risks of extreme events and disasters to advance climate change adaptation. A Special Report of Working Groups I and II of the Intergovernmental Panel on Climate Change (IPCC). Cambridge University Press, Cambridge, pp 109-230

Solman SA, Sanchez E, Samuelsson P, da Rocha RP, Li L, Marengo J, Pessacg NL, Remedio ARC, Chou SC, Berbery H, Le Treut H, de Castro M, Jacob D (2013) Evaluation of an ensemble of regional climate model simulations over South America driven by the ERA-Interim reanalysis: model performance and uncertainties. Clim Dyn 41(5-6):1139-1157. doi:10.1007/s00382013-1667-2

Sud YC, Walker GK, Kim JH, Liston GE, Sellers PJ, Lau WKM (1996) Biogeophysical consequences of a tropical deforestation scenario: a GCM simulation study. J Clim 9(12):3225-3247

Tiedtke M (1989) A comprehensive mass flux scheme for cumulus parameterization in large-scale models. Mon Weather Rev 117:1779-1800

UNFCCC, Conference of the Parties (ed) (2009) Report of the Conference of the Parties on its fifteenth session, held in Copenhagen from 7 to 19 December 2009. Addendum. Part
Two: Action taken by the Conference of the Parties at its fifteenth session

Voldoire A, Royer JF (2004) Tropical deforestation and climate variability. Clim Dyn 22(8):857-874. doi:10.1007/s00382-0040423-z

Voldoire A, Royer JF (2005) Climate sensitivity to tropical land surface changes with coupled versus prescribed SSTs. Clim Dyn 24(7-8):843-862. doi:10.1007/s00382-005-0014-7

Walker R, Moore NJ, Arima E, Perz S, Simmons C, Caldas M, Vergara D, Bohrer C (2009) Protecting the Amazon with protected areas. Proc Natl Acad Sci USA 106(26):10,582-10,586. doi:10.1073/pnas.0806059106

Xu L, Samanta A, Costa MH, Ganguly S, Nemani RR, Myneni RB (2011) Widespread decline in greenness of amazonian vegetation due to the 2010 drought. Geophys Res Lett 38(7). doi:10.1029/ 2011GL046824

Yin L, Fu R, Shevliakova E, Dickinson RE (2013) How well can CMIP5 simulate precipitation and its controlling processes over tropical South America? Clim Dyn 41(11-12):3127-3143. doi:10.1007/s00382-012-1582-y

Zhang H, Henderson-Sellers A, McGuffie K (1996) Impacts of tropical deforestation. Part I: process analysis of local climatic change. J Clim 9(7):1497-1517 